\title{
Вплив професійно-прикладної фізичної підготовки на самопочуття студентів старших курсів вищих навчальних закладів
}

\author{
С. М. Іващенко, В. В. Гузов \\ Національний університет фізичного виховання і спорту України, \\ Київ, Україна
}

\begin{abstract}
Резюме. Приведены данные о результатах применения специальных занятий по профессионально-прикладной физической подготовке студентов горных специальностей в Донбасском горно-металлургическом институте с точки зрения их влияния на показатели самочувствия студентов и их обращаемости за медицинской помощью. Установлено, что использование специальной круговой полосы препятствий в ходе профессиональноприкладной физической подготовки студентов старших курсов улучшает показатели их самочувствия и снижает показатели частоты обращений за медицинской помощью. Ключевые слова: профессионально-прикладная физическая подготовка, показатель частоты обращаемости за медицинской помощью, специалисты горного профиля, круговая полоса препятствий.
\end{abstract}

Summary. The article presents data on the results of the use of special sessions on professionalapplied physical training of students in the Donbass mining specialties Mining and Metallurgical Institute in terms of impact on the performance of these activities and their well-being of students seeking medical help. It was found that the use of a special circular obstacle in the course of professional-applied physical training of senior students of the school helps to improve the performance of their health and reduces the frequency parameters of calls for medical help.

Key words: vocational and applied physical training, the rate of frequency of seeking medical care, specialists mine profile, the circular obstacle.

Постановка проблеми. В Україні, як і в більшості держав світу, однією з найважливіших проблем сучасності $€$ розробка ефрективних заходів, спрямованих на збереження здоров'я населення в умовах погіршення екологічної ситуації та комплексна дія несприятливих чинників $[1,7]$.

Соціологічні дослідження, проведені в багатьох країнах світу, показують, що кількість осіб, які впевнені в тому, що для збереження здоров'я потрібно систематично займатися фрізичною підготовкою, щорічно збільшується [10]. Цим пояснюється стійка тенденція до збільшення кількості осіб, які прагнуть до підвищення індивідуального рівня фрізичної підготовленості, підтримання резистентності організму до дії несприятливих чинників навколишнього середовища, покращення настрою і самопочуття [2].

Результати наукових досліджень, що були проведені з метою вивчення впливу на організм людини фрізичних навантажень тренувального характеру, представлені в роботах учених України та інших держав $[4,8]$. Значну кількість робіт було присвячено вивченню ролі інноваційних технологій у процесі оптимізації режиму рухової активності різних категорій населення $[5,9]$.
Цікаві результати були отримані в ході дослідження впливу систематичних фрізичних тренувань на показники психологічного стану різних категорій населення в сучасних умовах $[3,6]$. Але, на жаль, до цього часу питання впливу занять 3 професійно-прикладної фрізичної підготовки спеціалістів, які працюють в особливих умовах (зокрема, фрахівців гірничого профрілю), на показники частоти їх звернень за медичною допомогою залишається ще недостатньо вивченим.

Мета дослідження - вивчення характеру впливу систематичних занять 3 професійноприкладної фрізичної підготовки спеціалістів гірничого профілю на їх самопочуття і показники частоти звернення за медичною допомогою.

Методи та організація дослідження. 3 метою вивчення впливу занять з професійно-прикладної професійної підготовки на стан самопочуття студентів старших курсів Донбаського гірничо-металургійного інституту було застосовано педагогічне спостереження, анкетування та бесіди. При цьому використовували спеціальну анкету, розроблену з урахуванням особливостей професійної діяльності респондентів, яка передбачала самооцінку ними свого самопочуття протягом усього періоду спостереження. 
Дослідження проводили з 26 вересня 2009 р. по 12 червня 2012 р. у Донбаському гірничометалургійному інституті. До участі в них було залучено 98 осіб, відібраних із числа студентів гірничих спеціальностей. Усіх студентів розподілили на дві рівноцінні групи (з дотриманням принципу спорідненості за показниками віку, статі та індивідуальних антропометричних і фізіологічних даних) - основну і контрольну (по 49 осіб у кожній). При цьому студенти контрольної групи протягом усього періоду спостереження займалися фрізичною підготовкою самостійно, а студенти основної - реалізовували індивідуальні програми професійно-прикладної фрізичної підготовки, призначені для фрахівців гірничих спеціальностей, і використовували для тренувань спеціальну кільцеву смугу перешкод.

3 метою отримання об'єктивних даних про показники самопочуття застосовували спеціальні анкети, в яких позначалися паспортні дані респондентів, їхні основні антропометричні параметри та результати оцінки самопочуття в різні періоди тренувального процесу. Це відповідало умовам застосування сучасного варіанта методики САН (самопочуття, активність, настрій), адаптованого до специфріки професійної діяльності даного контингенту спеціалістів.

У випадках, коли в іспитованих скарги на стан здоров'я були повністю відсутні, їх самопочуття оцінювали у 5 балів, за наявності незначних скарг, які не знижували спроможності до виконання тренувальних вправ, - у 4 бали. Якщо мало місце погіршення самопочуття, але воно суттєво не впливало на спроможність студентів до виконання тренувальних завдань, випробувані отримували 3 бали. При помірному зниженні спроможності до виконання передбачених програмою тренувальних навантажень виставляли 2 бали. Нарешті, якщо здатність до виконання вправ знижувалася суттєво, вони отримували 1 бал. У разі повної неспроможності до здійснення тренування бали не виставлялися.

Підсумковий аналіз отриманих у ході дослідження даних здійснювали за допомогою стандартних програм статистичного аналізу і пакета прикладних статистичних програм.

Результати дослідження та їх обговорення. У ході виконання зазначеного дослідження було отримано дані про динаміку змін показників самопочуття у студентів гірничих спеціальностей, які проходили навчання на III-V курсах Донбаського гірничо-металургійного інституту, на фоні застосування індивідуальних програм фрізичної підготовки професійно-прикладної спрямованості. При цьому студенти контрольної групи займалися фрізичною підготовкою самостійно, а студенти основної групи - за індивідуальними програмами та в умовах періодичного контролю з боку викладачів кафедри фрізичного виховання.

Слід зазначити, що обгрунтування і розробку індивідуальних програм професійно-прикладної фрізичної самопідготовки студентів гірничих спеціальностей здійснювали на основі вивчення рівня їхньої фрізичної підготовленості та з урахуванням стану здоров'я.

Для визначення інтегрованого показника самопочуття студентів застосовували спеціальну систему оцінювання. При цьому за допомогою методів анкетування і педагогічного спостереження було зібрано інформацію про зміни показників самопочуття студентів протягом усього періоду спостереження. Після цього було здійснено статистичну обробку отриманих даних і порівняння результатів дослідження в обох групах.

Застосування даної системи тестування студентів проводили щомісячно протягом третього, четвертого та п'ятого років навчання у вищому навчальному закладі. Це дозволило визначити основні тенденції щодо змін показників самопочуття студентів залежно від пори року або рівня інтенсивності навчального процесу.

Додатково визначали показник частоти звернень студентів за медичною допомогою за даними аналізу документів медичного обліку. Отримані результати представлено в таблиці 1.

Як бачимо із показників таблиці, у студентів основної групи, які займалися професійноприкладною фрізичною підготовкою під періодичним контролем інструкторів, інтегрований показник самопочуття протягом усього періоду спостереження прогресивно збільшувався, що свідчить про позитивний вплив такого виду підготовки на стан респондентів.

На відміну від цього, у студентів контрольної групи, які протягом III-V курсів займалися фрізичною підготовкою самостійно, інтегрований показник самопочуття залишився практично в межах вихідних значень. Крім того, було встановлено, що кількість звернень за медичною допомогою протягом третього року спостереження у студентів основної групи зменшилась на 28,6 \% порівняно

ТАБЛИЦЯ 1 - Значення інтегрованого показника самопочуття студентів

\begin{tabular}{|l|c|c|c|}
\hline \multirow{2}{*}{ Група } & \multicolumn{3}{|c|}{ Курс } \\
\cline { 2 - 4 } & III & IV & V \\
\hline Основна & $1314 \pm 7$ & $1456 \pm 9$ & $1628 \pm 11$ \\
Контрольна & $1327 \pm 7$ & $1334 \pm 8$ & $1320 \pm 7$ \\
\hline
\end{tabular}


3 першим роком, а у студентів контрольної групи вона залишилася на попередньому рівні.

Це підтверджує думку про позитивний вплив занять з профессійно-прикладної фрізичної підготовки на функціональний і психологічний стан студентів старших курсів вищих навчальних закладів гірничого профрілю.

\section{Висновки:}

1. Застосування індивідуальних програм професійно-прикладної фрізичної підготовки у студентів старших курсів вищих навчальних закладів сприяє підвищенню показників їхнього самопочуття та зумовлює зниження частоти їх звернень за медичною допомогою.

\section{Література}

1. Булатова М. М. Здоров'я і фрізична підготовленість населення України / М. М. Булатова, О. Т. Литвин // Теорія і методика фріз. виховання і спорту. - 2004. - № 1. C. 3-9.

2. Вайнбаум Я. С. Гигиена физического воспитания и спорта: учеб. пособие [для студ. высш. пед. учеб. заведений] / Я. С. Вайнбаум, В. И. Коваль, Т. А. Родионова. М.: Академия, 2003. - 240 с.

3. Выдрин В. М. Физическая культура как феномен культуры личности и общества / В. М. Выдрин, А. Н. Плешаков // Культура фриз. и здоровье. - 2005. - № 1. C. $23-27$.

4. ГуреВич И. А. Круговая тренировка при развитии фризических качеств. - 3-е изд. перераб. и доп / И. А. Гуревич. - Минск: Высш. шк., 1985. - 256 с.

5. Даниленко Л. І. Управління інноваційною діяльністю в загальноосвітніх навчальних закладах / Л. І. Даниленко. - К.: Міленіум, 2004. - 358 с.

6. КруцеВич Т. Ю. Формування фрізичної культури студентів у системі вищої освіти / Т. Ю. Круцевич, О. К. Марченко // Теорія і методика фріз. виховання і спорту. 2009. - № 2. - С. 79-81.

7. Концепція Загальнодержавної цільової соціальної програми «Здорова нація» на 2009-2013 роки. Розпорядження Кабінету Міністрів України від 21 травня 2008 р. № 731.

8. Линець М. М. Витривалість, здоров'я, працездатність: [монографрія] / М. М. Линець, Г. М. Андрієнко. - Л.: Штабар, 1993. - 129 с.

9. Суббота Ю. В. Оздоровчі рухові програми самостійних занять фрізичною культурою і спортом / Ю. В. Суббота. - К.: Кондор, 2007. - 164 с.

10. Яременко О. О. Фізична культура як неодмінна складова формування здорового способу життя молоді. Кн. 6 // О. О. Яременко, О. Д. Дубогай, Р. Я. Левін, Л. В. Буцька. - К., 2005. - 124 с.
2. У процесі підготовки студентів старших курсів вищих навчальних закладів гірничого профілю доцільно застосовувати індивідуальні програми профресійно-прикладної фрізичної підготовки під контролем викладачів кафедри фрізичного виховання.

3. Ефект покращення самопочуття та зниження показника частоти звернень за медичною допомогою, досягнутий завдяки застосуванню програм професійно-прикладної фрізичної підготовки, зумовлюється зростанням рівня фрізичної підготовленості студентів старших курсів вищих навчальних закладів гірничого профрілю та зміцненням їхнього професійного здоров'я.

\section{Preferences}

1. Bulatova M. M. Health and physical fitness of the population of Ukraine / M. M. Bulatova, A. T. Litwin // Theory and Methods of Physical Education and Sports. - 2004. N 1. - P. 3-9.

2. Weinbaum J. S. Hygiene of Physical Education and Sport: A Training Manual [for stud. Higher. ped. Textbook. institutions] / J. S. Weinbaum, V. I. Koval, T. A. Rodionova. Moscow: The Academy, 2003. - 240 p.

3. Vydrin V. M. Physical education as a cultural phenomenon of the individual and society / V. M. Vydrin, A. N. Pleshakov // Physical Culture and Health. - 2005. N 1. - P. 23-27.

4. Gurevich I. A. Circuit Training in the development of physical qualities. - 3rd ed. revised. and additional / I. A. Gurevich. - Minsk, High School., 1985. - 256 p.

5. Danilenko L. I. Management of innovative activity in secondary schools / L. I. Danilenko. - Kiev: Millennium, 2004. - 358 p.

6. Krutsevich T. U. Formation of physical training of students in higher education / T. U. Krutsevich, O. K. Marchenko // Theory and Methods of Physical Education and Sports. 2009. - N 2. - P. 79-81.

7. The concept of national targeted social program «Healthy Nation» in 2009-2013 years. The Cabinet of Ministers of Ukraine dated May 21, 2008 № 731 - R.

8. Linets $M$. M. Endurance, health, work capacity [monograph] / M. M. Linets, G. M. Andrienko. - Moscov: Shtabar, 1993. - 129 p.

9. Subbota U. V. Improving motor program self-study physical education and sport / U. V. Subbota. - Kiev: Condor, 2007. - $164 \mathrm{p}$.

10. Yaremenko A. A. Physical education as an indispensable component of a healthy lifestyle of young people. Book. 6 // A. A. Yaremenko, A. D. Dubogay, R. J. Levin, L. V. Butska. - Moscov, 2005. - 124 p. 